\title{
Research on Bond Issuers' Default Risk
}

\author{
$\mathrm{Ke} \mathrm{Bi}^{1, *}$ \\ ${ }^{I}$ Melbourne Business School, The University of Melbourne, Melbourne, Victoria 3053, Australia \\ ${ }^{*}$ Corresponding author. Email: kbpaperapply@163.com
}

\begin{abstract}
After analysing the RMB 3 billion credit bond default events of Yongcheng Coal and Electricity Group (Yongmei in the following paper) which is a local state-owned enterprise with AAA credit rating from its rating agency before the default event, some problems have been found. From Yongmei's consolidated financial statements and the parent company's financial statements, it can be found that both statements have a large proportion of short-term debts and their debts from banks are replacing with bond debts. In contrast to the consolidated balance, the parent company has only RMB 2.7 billion in cash and cash equivalents. As the parent is the subject of debt and repayment, it has insufficient solvency, especially in the short term. Besides, from the rating agency's rating reports and announcement, the rating model uses EBIT and EBITDA as profit indicators and all data from consolidated statements, which are mismatched with the subject of bonds. Hence, it left loopholes to the parent company to upgrade its rating, to 'transfuse blood' to its loss-making subsidiaries, or to evade debts. Ultimately, according to these findings, suggestions are provided to debt issuers, regulators, institutional investors and rating agencies.
\end{abstract}

Keywords: Bond Default, Default Risks, Evading debts, Rating Failure

\section{INTRODUCTION}

\subsection{Research Background}

Since 2018, China's bond default risk has increased significantly, the number and magnitude of bond defaults have enlarged, default events are getting normal, and diversification of default entities has risen. With the introduction of financial deleveraging policies, the implementation of new asset management regulations, and the frequent occurrence of corporate bond defaults, in contrast to the interest rate bond market, the credit bond market has taken a sharp turn. Private enterprises were the hardest hit. However, among the default entities in 2020, defaults of local-state-owned enterprises with high-grade bond rating have dramatically increased. Such as Tsinghua Unigroup, Yongcheng Coal and Electricity Group, Brilliance Auto, and Peking University Science Park Construction and Development Co. These defaults have greatly shocked the belief in state-owned firms in the bond market about that they will not fail.

\subsection{Research Significance}

Since China's bond market resumed the issuance of government bonds in 1981, as state-owned enterprises have invisible guarantees from the government, there has been no substantial default by state-owned enterprises for a long time. The beliefs in state-owned enterprises caused by the government's underwriting behaviour have distorted the risk awareness of market participants about bond defaults to a certain extent. There is a lack of some real defaults, and bond default risk measurement and other research have not played an important role in risk warning in China's bond market. In-depth analysing more typical bond default cases will help enrich and deepen the research on financing risks in the China capital market and bond default theories. It will be conducive to financing institutions' reasonable financing, regulatory agencies' effective supervision, investors' correct investment and intermediaries, especially credit rating agencies risk assessment.

\section{LITERATURE REVIEW}

\subsection{The Theory of Bond Default Risk}

Bond default mainly refers to the failure of the bond issuer to pay the due principal, interest or other contractual obligations in full on time; or when the contract has not yet expired, the issuer could not perform the contract, and the bond issuer has not been able to propose a solution timely, thereby causing a breach of 
contract (Bai, 2020).[1] The three major international rating agencies (Fitch, Standard \& Poor's, Moody's) define bond defaults mainly including, 1 . failure to repay the principal and interest on the maturity date; 2 . enterprise application for bankruptcy, liquidation or custody; 3. enterprise debt replacement Or restructuring plan (Cheng \& Zhu, 2020).[2]

\subsection{Measurement of Default Risk}

Early credit risk assessment relied on the professional knowledge and judgment of experts, which is highly subjective. Conclusions of different experts may vary greatly. Such as "5C", "5W" and "CAMEL" analysis method. Take "5C" as an example: repayment ability (Capacity), guarantee (Collateral), operating conditions (Condition), capital strength (Capital) and moral quality (Character). Comprehensive qualitative analysing of the issuer, quantifying its five elements to obtain the risk level (Shi, 2011).[3] In contrast to traditional methods, modern methods are using mathematical algorithms on established models to measure bond defaults risks.

Current methods and models mainly include:

\subsubsection{Static analysis}

In 1968, Altman established a 5-factor linear discriminant model - the Z-score model. This model is suitable for judging the financial crisis of listed manufacturing companies.[4] The Z' and Z" models proposed in 1977 and 2011 respectively: The $Z^{\prime}$ model is suitable for non-listed companies, the $Z^{\prime \prime}$ model is suitable for both listed companies and non-listed companies, it can also be used for the financial risk measurement of non-manufacturing companies.[5][6] Zhang and Zeng (2004) confirmed that the credit rating of listed companies in China has a good correlation with the $\mathrm{Z}$ value[7].

\subsubsection{Dynamic analysis}

KMV (1997) proposed the KMV model, which uses the option pricing formula, using the company's financial and capital market data to calculate the company's default distance (DD) to predict the company's expected default rate.[8] The model uses market current conditions instead of historical data to calculate the probability of default. The biggest advantage is it's forward-looking and the results are time sensitive. Jiang (2020) selects a total of 2314 samples from January 2013 to November 2019, of which 102 bond issuers defaulted to build an evaluation model for the default risk of the issuing company. The model's prediction accuracy rate for defaulting companies is as high as $81.4 \%$.[9] It can help credit bond market participants to evaluate bond issuers, thereby playing a role in risk screening. Duan (2012) compared the applicability of China's capital market between the $\mathrm{Z}$ model and the KMV model by selecting
424 companies. These companies are divided into two groups, ST and non-ST, and calculated the $\mathrm{Z}$ value and DD value respectively. It shows that although both the $Z$ model and the KMV model can be applied to the risk measurement of China's capital market, the $\mathrm{Z}$ model predicts better results. [10]

\subsection{Treatment of Default Risk}

\subsubsection{Beforehand}

$\mathrm{Yu}$, et al. (2016) proposed that China's corporate bond market can gradually try the mode that investors directly pay credit rating agencies. Establishing common interests between investors and rating agencies to more fair credit ratings.[11] Zhao (2018) said that bondissuing companies should rationally recognise the pros and cons of financial leverage, and the level of corporate leverage must match profitability. Only the company's income is greater than the cost of debts, the issued bonds can be profitable. Avoiding blindly increasing financial leverage in pursuit of income. Excessive financial leverage and debt burden pressure will increase the company's bond default risk.[12] Zhang (2018) advocated improving the bond market default risk handling mechanism and strengthening the establishment of investor protection systems; continuously improving investors' risk identification capabilities, promoting the development of the credit derivatives market, and providing investors with effective tools to diversify risks.[13] Zhang and Zhang (2020) points out that the supervision of China's bond market is a multi-sector decentralized supervision system and proposed to adopt a multi-level centralized supervision model. Only one top security regulatory agency to regulate and speed up the implementation of policies, and improving the low efficiency caused by overlapping supervision. Credit rating methods should also consider and quantify the industry status of the company, the company's financial status, and the macro environment. [14]

\subsubsection{In the event}

Gao (2017) believes that it is necessary to improve the legal system and strengthen the responsibilities of bond market intermediaries; establish a fiduciary management system that matches responsibilities and rights, clarify the specific responsibilities of corporate bond trustees for continuous supervision; improve the judicial relief system, and strengthen bond market investor protection.[15] Zhang (2017) proposed to establish a corporate debt risk early warning mechanism, strengthen the internal control system of accounts receivable, and establish a bond financing budget and sinking fund system from the perspective of enterprises; during the debt default negotiation period, modify debt conditions, and establish a corporate bond insurance 
system.[16] Hou (2020) concluded that China's bond default settlement methods mainly include self-raised funds, third-party compensation, debt restructuring, bankruptcy reorganization and so on.[17]

\subsubsection{After the default}

Liu and Yan Li (2016) said that with the maturity and the increasing degree of marketization of China's bond market, bond defaults are inevitable. It is necessary to change the mechanism that bonds are implicitly guaranteed by the government to reverse market malformations. As bond defaults are normalising, it is necessary to build and improve bond default risk constrain mechanisms, and further improve the defaulted bonds disposal mechanism.[18] Feng and Duan (2017) proposed that from the perspective of legal logic, private financial law based on civil and commercial rules should be the core, and public law guidance led by financial regulatory rules should be on protection purposes. In specific operations, it is necessary to develop a bankruptcy reconciliation system, establish a bond default payment system, reform the responsibilities of bond trustees.[19] Ruan (2019) suggested that defaulted bonds can be resolved through a unified cross-market default bond transaction system.[20]

Since March 1, 2020, the new Securities Law has been officially implemented, and the bond market has moved from an approval system to a registration system. It is expected that the transparency of information disclosure and investor protection will be significantly improved. At the same time, with the lowering of the bond issuance threshold and the marketization of bond pricing. (High Yield Bond Research Group of Golden Credit Rating, 2020) [21]

\subsection{The Debt Evasion in Bond Default}

Evasion of debt is that the debtor can repay but deliberately refuses to. This behaviour completely violates the minimum awareness of rules and the spirit of contract in the market economy. It is trampling on market discipline and make market expectations "unpredictable". It fundamentally penetrates the cornerstone of the credit debt and the entire capital market's orderly development. $\mathrm{Lu}$ (2011) concluded that the main forms of corporates' evasion of bank debts including bankruptcy and corporate restructuring. He said that it is crucial to strengthen the construction of financial legal systems. Besides, it is important to improve the bankruptcy Legal system, the internal control mechanism of banks, and the quality of bank employees. [22] Jin (2016) points out that debt evasion methods have been upgraded by repurchasing mortgage assets at a low price, purchasing large insurances, and using the legal provisions of "criminal law before civil law" to delay the case. He proposed to establish a comprehensive credit information sharing platform and to overcome local protectionism. [23] Chen (2019) said that the most serious part of the financial crisis is the evasion of debts, which is also the most common problem in the financial industry. It is suggested that the financial prevention system can comprehensively and effectively inspect financial assets, review financial statements to reduce the occurrence of financial risks and ensure the safety of financial funds. To supervise financial management, a risk responsibility system can be implemented to clarify the detailed rules of responsibility to fundamentally eradicate the problem of the inaction of financial institutions. [24]

\section{CASE STUDY}

\subsection{Overview of Yongcheng Coal and Electricity Group's Bond Default}

On November 10, 2020, the "20 Yongmei SCP003" 1 billion Chinese yuan bond of Yongcheng Coal and Electricity Holding Group failed to pay interest, which constituted a substantial default. Yongmei is a stateowned enterprise that subjects to the highest AAA rating. However, just before the breach of contract, it issued a 1 billion " 20 Yongmei MTN006". The default exceeded market expectations. From the public information, Yongmei still can pay debts, and theoretically should not default. In terms of bank credit, at the beginning of 2020, Yongmei's controlling shareholder Henan Energy Chemical Industry Group Co., Ltd. has remaining 100.8 billion Chinese yuan credit line obtained from major lending banks. At the end of 2020 Q3, the consolidated balance sheet shows that Yongmei's cash and equivalent balance was 32.821 billion Chinese yuan. Therefore, whether from the banks' remaining credit line or the latest cash balance, in facing short-term financing of 1 billion Chinese yuan, the company would not have breached the contract at that moment. Subsequently, on November 17, Yongmei announced again that the company's liquidity was insufficient, and there was uncertainty in the redemption of the ultra-short term "20 Yongmei SCP004" and "20 Yongmei SCP007". These two bonds should be redeemed on November 22 and 23, and the principal and interest payable amounts are 1.032 billion yuan and 1.025 billion yuan.

Although later Yongmei has paid RMB 32,385,200 of the redemption interest of " 20 Yongmei SCP003", the bond principal is also being raised. However, even if Yongmei repaid the RMB1 billion principal, it still faces the maturity or repurchase of RMB 10 billion in 2021.

\subsection{Rating Failure}

In a self-discipline investigation by the National Association of Financial Market Institutional Investors (NAFMII) on the intermediaries related to Yongmei Group's debt financing instruments, some intermediaries were suspected of violating the interbank bond market 
self-regulatory rules including lead underwriters such as Industrial Bank, China Everbright Bank and Zhongyuan Bank, as well as rating agency China Cheng Xin International Credit Rating Co. Ltd.(CCXI) and accounting firm Sigma Certified Public Accountants.

In the rating system of the rating agency of Yongmei CCXI, the description of the AAA rating is: "The subject has a very strong ability to repay debts and it will not affect even in the adverse economic environment, the risk of default is extremely low."[25] Before the default event, CCXI's announcement to maintain the AAA subject-rating of Yongmei also mentioned coal price fluctuations, the company's rising debt scale, the increase in the proportion of short-term debt, the increase in financial expenses, and the largely related party receivables.[27] The rating agency still maintained the AAA rating is based on its rating model that the analysis of Yongmei's consolidated statement, the available shareholder/government external support rating, and the final rating voted by the expert judges. The main basic scoring part is to select some financial ratios and other indicators about the profitability, financial policy and solvency, scale, and operational strength, which is aa+. First of all, the support adjustment scores mainly come from Yongmei's status as a state-owned enterprise and have previously had a relatively large financial support by its controlling shareholder which has the background of State-owned Assets Supervision and Administration Commission of the State Council (SASAC). This is also known as the "state-owned enterprise belief" of the bond market which comes from the belief of rigid payment from local governments to local state-owned enterprises. However, this time, the corresponding local government did not mobilize funds to support Yomgmei, Yongmei negotiated with creditors to extend the bond payment period. Ming Zhang, deputy director of the Institute of Finance of the Chinese Academy of Social Sciences, wrote that to local governments, local financing platforms are more important than local state-owned enterprises (industrial enterprises). This means when resources are limited, the local government may firstly protect the financing platform. Also, before the support rating adjustment, the base score alone was already aa+. In particular, the profit-related indicators all use EBIT, EBITDA and other profit values without deducting part of the expenses. These special profits exclude the interference of some expenses, but the final profit of the company is still the net profit. Not using the net profit at all reduces the accuracy of the scoring and allows the company to utilise those excluded expenses to raise the rating. More importantly, it is a mismatch between the bond issuer and indicators selected. The net profit attributable to the parent in the consolidated statements of Yongmei has been negative for three consecutive years and the amount magnitude is bigger than the net profit. The parent company is the subject of bond issuance, whereas inside of parent company, values in the scoring model are all related to the consolidated statement. As the result, the scoring model does not properly reflect Yongmei's bond default risks. There are loopholes that the parent company can take advantages of them to upgrade its rating, to 'transfuse blood' to its subsidiaries, or to evade debts.

\begin{tabular}{|l|r|r|r|r|r|}
\hline \multicolumn{7}{|c|}{ Table 1: Solvency ratios. Source: Wind } \\
\hline & $2020 / 9 / 30$ & $2019 / 12 / 31$ & $2018 / 12 / 31$ & $2017 / 12 / 31$ & $2016 / 12 / 31$ \\
\hline Current ratio & 0.89 & 0.76 & 0.81 & 0.68 & 0.63 \\
\hline Quick ratio & 0.85 & 0.72 & 0.69 & 0.55 & 0.47 \\
\hline Cash ratio & 0.5 & 0.48 & 0.45 & 0.3 & 0.26 \\
\hline Interest coverage ratio & - & 1.11 & 1.88 & 2.07 & - \\
\hline Conservative quick ratio & 0.83 & 0.69 & 0.67 & 0.52 & 0.44 \\
\hline Assets and liabilities (\%) & 77.84 & 76.71 & 77.36 & 80.01 & 79.44 \\
\hline Cash to maturity debt ratio (\%) & 11.1 & 8.98 & 19.08 & 18.61 & 19.47 \\
\hline Total current liabilities/liabilities (\%) & 72.88 & 74.38 & 71.27 & 71.83 & 66.3 \\
\hline
\end{tabular}

\begin{tabular}{|l|c|c|}
\hline \multicolumn{2}{|c|}{ Table 2: Yongmei's ratios' ranking in the industry. Source: Wind } \\
\hline \multicolumn{1}{|c|}{ Yongcheng Coal and Electricity Holding Group Co., Ltd. 2020Q3 } & $\begin{array}{c}\text { Enterprise Position } \\
(\%)\end{array}$ \\
\hline ROE & -3.2038 & 90 \\
\hline Current ratio & 0.8925 & 40 \\
\hline Quick ratio & 0.8542 & 27 \\
\hline Net interest rate & 1.0703 & 78 \\
\hline Inventory turnover & 9.7542 & 40 \\
\hline Assets and liabilities & 77.8425 & 92 \\
\hline
\end{tabular}




\begin{tabular}{|l|c|c|}
\hline Total assets (100 million) & 1726.49854 & 27 \\
\hline Net profit (100 million) & 4.763839273 & 66 \\
\hline Accounts receivable turnover rate & 11.3764 & 20 \\
\hline Net cash flow from operating activities $(100 \mathrm{~m})$ & 73.83835986 & 81 \\
\hline Net cash flow from investment activities $(100 \mathrm{~m})$ & -59.12633271 & 64 \\
\hline Owners' equity attributable to the parent company $(100 \mathrm{~m})$ & 112.9007673 & \\
\hline
\end{tabular}

\subsection{Financial Risk}

\subsubsection{Solvency (ratios from Table 1)}

\subsubsection{Low current ratio}

The current ratio is the ratio of the company's current assets to the company's current liabilities. It indicates the company's ability to use internal current assets to repay debts in the short-term, and it is positively related to its short-term liquidity. This ratio's benchmark is generally considered to be 2. Although Yongmei's cash balance at the end of 2018 and other receivables at the end of 2020 has risen sharply, resulting in a slight increase in the current ratio, it is still far below 2 and is at the middle position of the industry. It shows that the current liabilities of enterprises are far greater than the current assets.

\subsubsection{Low quick ratio}

The quick ratio is the company's quick assets to the company's current liabilities. The balance of the company's current assets minus the inventory is the quick asset. The quick ratio supplements the current ratio. The quick ratio can better reflect the company's shortterm solvency. Its general benchmark is around 1. If the ratio is much lower than 1, then the company's shortterm debt solvency is weak. If it is too higher than 1 , it means that there is a problem with the company's capital operation. For example, accounts receivable occupies too much capital, which reduces capital efficiency and increases the opportunity cost. Although Yongmei's quick ratio is at a relatively high rank within the industry and has shown an upward trend in the past five years, it has been below 1 .

The too low current ratio and low quick ratio reflect Yongmei's weak short-term solvency and it has high financial risk.

\subsubsection{High cash ratio}

The cash ratio is the percentage of the company's quick assets minus the accounts receivable then divided by the company's current liabilities. It reflects the company's ability to directly pay current debts with monetary funds instead of relying on inventory sales and accounts receivable to cash out. It can most intuitively reflect the direct solvency of an enterprise. It is generally considered to be safe if it is above $20 \%$. However, too high means that the company's assets withheld have not been properly used. In the past five years, the consolidated statement cash ratio of Yongmei has been higher than $20 \%$ and gradually rises to $50 \%$ in Q3 2020 .

\subsubsection{Decreasing interest coverage ratio}

The interest coverage ratio is the multiple of the net operating cash flow as the interest expense. It is more reliable than the income-based interest protection multiple because the actual interest payment is cash, not income. It reflects the company's ability to repay interest expenses in cash. The larger the ratio, the stronger the company's profitability. If the ratio is too small, the company has difficulties in paying interest and the company's cash solvency is low. The general benchmark should be at least greater than 1 . It has been declining from 2.07 in 2018 to 1.11 in 2019, which is close to the threshold (1) and the net cash flow in 2020Q3 is negative. This represents the gradual decline in the ability of Yongmei's operations to obtain cash solvency.

\subsubsection{High asset-liability ratio}

The debt-to-asset ratio refers to the ratio of the total liabilities of the company to the total assets of the company. As a comprehensive indicator reflecting the level of a company's debt, the debt-to-asset ratio refers to the extent to which a company uses creditors' funds to operate the company. Yongmei Group's debt-to-asset ratio is around $80 \%$ for the last 5 years. Besides, it is at the bottom $92 \%$ of its peer ranking, which reflects that the company's debt has been high.

\begin{tabular}{|l|r|r|r|r|r|}
\hline \multicolumn{7}{|c|}{ Table 3: Account receivable turnover and days Source: Wind } \\
\hline & $2020 / 9 / 30$ & $2019 / 12 / 31$ & $2018 / 12 / 31$ & $2017 / 12 / 31$ & $2016 / 12 / 31$ \\
\hline Accounts receivable turnover & 11.38 & 14.35 & 15.59 & 10.96 & 7.8 \\
\hline Days Sales outstanding & 23.73 & 25.1 & 23.1 & 32.84 & 46.14 \\
\hline
\end{tabular}




\subsubsection{Operational capability}

\subsubsection{Analysis of accounts receivable}

From Table 3, accounts receivables are the accounts receivable that are occupied by customers in daily business activities. Accounts receivable turnover is net income from credit sales to the average accounts receivable over a period of time, representing the number of times that the company's receivables are turned into cash in a fixed period. The accounts receivable turnover days indicate the average number of days from the sale of goods to the recipient of the cash. In the past five years, the inventory turnover ratio increased and the number of days dropped significantly from 46 days to 24 days. Under normal circumstances, the accounts receivable turnover ratio is around 3, Yongmei's ratio is much higher than 3 in the past five years. Furthermore, it ranks in the middle of its industry in the current period. The time to get cash is getting shorter and shorter, and the debt solvency is getting better.

\begin{tabular}{|l|r|r|r|r|r|}
\hline \multicolumn{7}{|c|}{ Table 4: Current asset ratios. Source: Wind } \\
\hline & $2020 / 9 / 30$ & $2019 / 12 / 31$ & $2018 / 12 / 31$ & $2017 / 12 / 31$ & $2016 / 12 / 31$ \\
\hline Other receivables & $26,941.83$ & $15,469.47$ & $16,032.25$ & $14,325.66$ & $8,537.48$ \\
\hline Total current asset & $87,418.35$ & $71,447.41$ & $72,307.55$ & $55,656.20$ & $45,603.57$ \\
\hline Current asset turnover & 0.56 & 0.65 & 0.77 & 0.81 & 0.74 \\
\hline Cash and cash equivalents. & $46,967.87$ & $42,087.92$ & $37,666.23$ & $20,865.96$ & $14,626.17$ \\
\hline
\end{tabular}

\subsubsection{Analysis of Current Asset Turnover Ratio}

From Table 4, current assets are assets that can be realised or used within a business cycle of one year or more than one year, they are highly liquid. The current assets of Yongmei Group have continued to rise. However, the turnover ratio of current assets has dropped from 0.74 to 0.56 . This ratio is the net income from the main business during the period to the total average current assets of the enterprise. It indicates the turnover speed of the current assets within the enterprise. The larger the ratio, the faster the turnover of the company's current assets, and the higher the efficiency of corporate capital utilisation.

The main reason for the year-on-year decline is that the non-current assets increase at a higher rate than (1.92 times compared to 2016) operating income (1.29 times). Among the non-current assets, cash and cash equivalents and other receivables were the main increase items (3.21 and 3.16 times respectively). The increase in current assets has strengthened the solvency, but the decline in its turnover rate indicates that Yongmei is using current assets inefficiently.

\begin{tabular}{|l|r|r|r|r|r|}
\hline \multicolumn{7}{|c|}{ Table 5: Inventory related ratios. Source: Wind } \\
\hline & $2020 / 9 / 30$ & $2019 / 12 / 31$ & $2018 / 12 / 31$ & $2017 / 12 / 31$ & $2016 / 12 / 31$ \\
\hline Inventory & $3,748.71$ & $3,923.36$ & $10,210.41$ & $11,094.56$ & $11,312.03$ \\
\hline Inventory turnover & 9.75 & 5.13 & 3.58 & 2.88 & 2.54 \\
\hline Days sales inventory & 27.68 & 70.2 & 100.47 & 125.11 & 141.93 \\
\hline
\end{tabular}

\subsubsection{Analysis of inventory turnover ratio}

From Table 5, The inventory turnover ratio indicates the ability of an enterprise to sell products and its level of inventory management. It is the cost of sales of an enterprise over the average inventory. The higher the inventory turnover ratio, the stronger the liquidity of the inventory and the shorter the time it takes for the company's inventory to be turned into operating income. It is an important ratio for the company's short-term debt solvency. It can be seen from Table 5 that the company's inventory has dropped significantly in 2019. With the small changes in operating costs, the inventory turnover rate in the past two years has risen sharply and the number of turnover days has dropped dramatically. In the industry ranking, its inventory turnover ratio is in the upper-middle level (40th).

Table 6: Profitability. Source: Wind

\begin{tabular}{|l|c|c|c|c|c|}
\hline & $2020 / 09 / 30$ & $2019 / 12 / 31$ & $2018 / 12 / 31$ & $2017 / 12 / 31$ & $2016 / 12 / 31$ \\
\hline Net profit (millions) & 476.38 & 994.98 & 337.34 & $1,166.48$ & $-2,196.09$ \\
\hline Sales margin (\%) & 1.07 & 2.12 & 0.69 & 2.83 & -6.35 \\
\hline Gross profit margin (\%) & 15.93 & 22.93 & 22.1 & 21.82 & 14.63 \\
\hline Return on equity(annualized) (\%) & -4.27 & -14.12 & -14.23 & 0.36 & -27.46 \\
\hline Rate of Return on Assets (annualized) (\%) & 0.38 & 0.61 & 0.22 & 0.83 & -1.59 \\
\hline
\end{tabular}




\begin{tabular}{|l|c|c|c|c|c|}
\hline \multicolumn{7}{|c|}{ Table 7: Equity and net profit attributes of Yongmei's consolidated statement. Source: Wind } \\
\hline & $2020 / 9 / 30$ & $2019 / 12 / 31$ & $2018 / 12 / 31$ & $2017 / 12 / 31$ & $2016 / 12 / 31$ \\
\hline Total owners' equity & $38,254.89$ & $38,255.21$ & $36,747.87$ & $28,390.65$ & $28,447.70$ \\
\hline Owner's equity attributes to parent company & $11,290.08$ & $8,639.77$ & $10,017.72$ & $6,055.31$ & $6,210.24$ \\
\hline Non-controlling interests & $26,964.81$ & $29,615.44$ & $26,730.14$ & $22,335.34$ & $22,237.46$ \\
\hline Net profit & 476.38 & 994.98 & 337.34 & $1,166.48$ & $-2,196.09$ \\
\hline Minority interest income & 795.64 & $2,311.97$ & $1,480.86$ & $1,144.41$ & -89 \\
\hline Net profit belongs to the parent company & -319.25 & $-1,316.99$ & $-1,143.52$ & 22.07 & $-2,107.09$ \\
\hline
\end{tabular}

\subsubsection{Profitability deteriorated}

From Table 6, return on equity (ROE) is net profit to the net asset, it indicates the efficiency of the company to use corporate equity. The higher the ratio, the better the company's operations and the higher the company's benefits. Except for 2017, Yongmei's return on equity has increased but was all negative for the other four years. Its net profits were negative and increasingly worse in the last four years. It is at the bottom $90 \%$ in its industry ranking in $2020 \mathrm{Q} 3$.

Return on total asset (ROA) is another strong indicator of a company's profitability. It refers to net profit as the average total asset. It reflects the efficiency of the company's use of the total asset, as well as the company's managers' level of control. The higher the ratio, the higher the output efficiency of the company's total asset, and the higher the control level of corporate management. The ROA has increased from the end of 2016 to Q3 2020, which indicates that the return on investment and profitability have improved. The main reason for the sharp rise in 2017 was the substantial increase in net profit which turned the company from loss to positive profit. However, net profit has gradually declined until now (2020 Q3) (Table 7). In the third quarter of 2020, Yongmei's gross profit margin and net profit margin have dropped significantly comparing with previous years, representing a substantial decline in its profitability. It is mainly caused by the extremely high total operating cost which has severely weakened Yongmei's profitability.

From Table 8, the main subsidiary information, Yongmei (the parent company) owns a small proportion of subsidiaries with positive net profits, especially in the subsidiary Yongmei Group Co., Ltd. which accounts for a large proportion of consolidated statements' net profits (only $61.9 \%$ ). In contrast, the parent company owns a higher proportion of subsidiaries with negative net profits. As a result, the net profit attributes to the parent company in the consolidated statement is much lower than the minority interest income. Besides, these voting rights structure has not changed significantly in recent years.

\begin{tabular}{|l|c|c|c|}
\hline \multicolumn{4}{|c|}{ Table 8: Main subsidiaries of Yongmei as at the end of 2019} \\
\hline Controlled company & Relationship & Voting rights \% & Net profit \\
\hline Yongmei Group Co., Ltd. & Subsidiary & 61.9 & $370,199.70$ \\
\hline Henan Yong Coal Industry Co., Ltd. & Subsidiary & 85 & $18,766.15$ \\
\hline Guizhou Yongmei Technology Development Co., Ltd. & Subsidiary & 100 & $5,771.81$ \\
\hline Yuzhou Zaoyuan Coal Industry Co., Ltd. & Subsidiary & 51 & $3,301.27$ \\
\hline Guizhou Jinhong Chemical Co., Ltd. & Subsidiary & 87.28 & $-4,076.59$ \\
\hline Guizhou Zikuang Energy Development Co., Ltd. & Subsidiary & 100 & $-10,773.97$ \\
\hline Shangqiu Yudong Power Generation Co., Ltd. & Subsidiary & 100 & $-15,978.11$ \\
\hline Henan Zhongmei Aluminum Co., Ltd. & Subsidiary & 70 & $-16,234.47$ \\
\hline Kaifeng Air Separation Group Co., Ltd. & Subsidiary & 100 & $-20,498.79$ \\
\hline Xinxiang Zhongxin Chemical Co., Ltd. & Subsidiary & 100 & $-26,790.96$ \\
\hline Henan Longyu Coal Chemical Co., Ltd. & Subsidiary & 93.44 & $-61,037.61$ \\
\hline
\end{tabular}

\begin{tabular}{|c|c|c|c|c|c|}
\hline \multicolumn{1}{|c|}{ Table 9: Cash flows. Source: Wind } \\
\hline & $2020 / 9 / 30$ & $2019 / 12 / 31$ & $2018 / 12 / 31$ & $2017 / 12 / 31$ & $2016 / 12 / 31$ \\
\hline Net cash flow from operating activities & $7,383.84$ & $5,830.44$ & $9,795.18$ & $8,341.23$ & $7,192.53$ \\
\hline Net cash flows from investing activities & $-5,912.63$ & $-4,805.23$ & $-2,936.34$ & -440.48 & $-2,782.57$ \\
\hline
\end{tabular}




\begin{tabular}{|c|c|c|c|c|c|}
\hline Net cash flow from financing activities & $-3,220.31$ & -420.89 & $5,569.99$ & $-1,537.78$ & $-2,549.89$ \\
\hline Net increase in cash and cash equivalents & $-1,747.14$ & 604.68 & $12,430.87$ & $6,360.75$ & $1,862.62$ \\
\hline $\begin{array}{c}\text { Cash and cash equivalents at the beginning } \\
\text { of the period }\end{array}$ & $34,568.30$ & $33,296.83$ & $20,865.96$ & $14,505.22$ & $12,763.55$ \\
\hline $\begin{array}{c}\text { Cash and cash equivalents at the end of the } \\
\text { period }\end{array}$ & $32,821.15$ & $33,901.51$ & $33,296.83$ & $20,865.96$ & $14,626.17$ \\
\hline
\end{tabular}

\subsubsection{Cash flow analysis: Insufficient current cash flow. Table 9.}

The company's net cash flow from operating activities had increased from 2016 to 2018. After a huge decline in 2019, in 2020, only the first three quarters' cash flow has exceeded 2019, which represents an improvement in operating conditions in 2020 comparing with 2019. Its cash flow from operating activities is at the top $20 \%$ of that of its peers. However, in the past three years, companies' investment has expanded significantly, especially in 2019 , which was $82 \%$ of net operating cash in the same period. Except for the cash inflow caused by the sudden and large increase in fundraising in 2018, Yongmei's net cash from financing activities was negative. Especially in 2020Q3, it was twice the cash from non-financing activities. It is at the bottom $81 \%$ in the industry which indicates that Yongmei has pated back more than other companies in the industry. Whereas Yongmei's net debt repayment has not reduced its outstanding debts, which shows that it may borrow new debts to repay the old. Ultimately, even the net cash change of Yongmei has been positive from 2016 to 2019, the net cash value is negative 1.7491 billion Chinese yuan in the first three quarters of 2020 which is equivalent to $24 \%$ of the current net operating cash flow. This suggests that Yongmei's cash from operating is not enough for current investment and repayment of financing.

\subsubsection{Default Reasons}

There are two main reasons for Yongmei's default. Firstly, due to the current economic condition and government policy of "decreasing the leverage", it is difficult to raise bond financing in the current bond market, and Yongmei is facing the pressure of concentrated redemption recently. Secondly, Yongmei's main business is coal mining, the coal prices have decreased from a high point and are in a volatile stage. Creditors have lowered their expectations for coal companies like Yongmei. Since the supply-side structural reforms from 2017 in China, Yongmei has not been able to divest its loss-making non-coal businesses, it is hoping to rely on refinancing.

The signal has already appeared. Although Yongmei's coal sales increased from 2017 to 2019, the non-coal business accounts for more than half of the group's revenue was difficult. From the perspective of the business structure, the coal business accounts for nearly half of revenue but contributes nearly $90 \%$ of profits. In recent years, profits have been stable, with a gross profit margin of about $40 \%$; the logistics business also accounts for $42 \%$, but profitability is low; chemical business is a serious drag on Yongmei's performance. Besides, Yogmei's debt structure is another problem, the company has been borrowing the short to paying the long. Current liabilities account for an increasingly high proportion of liabilities. In conclusion, as the profitability of the enterprise is relatively weak and leveraging the debt repayment problem, debt repayment pressure has further increased. Hence, Yongmei's liquidity has been depleted.

In the past, the market tried to bet that state-owned enterprises would not default or the government would guarantee the repayment. However, facts have proved that state-owned enterprises are no longer risk free debt issuers.

\subsection{Debts Evading Suspicions}

The market's concerns about Yongmei's bond default are evading debts. That is, as the parent company, Yongmei issue bonds for its non-core subsidiaries, which increased its leverage for its loss-making subsidiaries. Hence, it increased the parent company's financial risk and depleted the whole group's liquidity.

\subsubsection{Announcements of related official and organisations}

Yongmei Holdings has been questioned about capital occupation, financial fraud, and dishonest debt issuance. On November 24, 2020, the National Association of Financial Market Institutional Investors (NAFMII) issued a self-discipline announcement against Yongcheng Coal and Electricity Group. This announcement is regarding Yongmei's inaccurate and incomplete information disclosure, the controlling shareholder occupied the company's assets, and a large number of monetary funds were transferred to the controlling shareholder. Moreover, gratuitous transfer of relevant assets and the change of fundraising purposes were not disclosed in time during the bond financing period.[26] 


\subsubsection{The parent company's weak solvency}

The parent company is the financing entity. Solvency ratios from the parent company's statement are more relevant to its corporate bonds. In the third quarter of 2020 , the ending cash and cash equivalents of the parent company was only 2.8 billion Chinese yuan. In contrast, the parent company has a heavy burden of interestbearing debt. The debt structure is that the short-term debts proportion increasing, and falling bank borrowings while bond financing is rising.

\subsubsection{Yongmei's funds were largely occupied.}

Its internal non-coal core businesses and related parties occupied a serious amount of funds. Hence, the parent company's cash flow is being continuously tightened. In recent years, the amount of other receivables of the parent company has fluctuated upwards. In the third quarter of 2020, it climbed to 29 billion Chinese yuan, reaching a recorded high. It represents $46 \%$ of the parent company's total assets, where the main counterparties are the related parties of Yongmei's controlling shareholder.

\subsubsection{New bond issuing before the default}

On October 22, 2020, before the default, Yongmei Group issued a 1 billion Chinese yuan bond "20MTN006" from the inter-bank market. However, all funds were used to repay its old bond "17MTN001" which dues on October 30.

\begin{tabular}{|c|c|c|c|c|}
\hline \multicolumn{4}{|c|}{ Table 10: Data about Yongmei's Gratuitous Transfers. Amounts in (ten thousand yuan). Source: Wind } \\
\hline & Net assets & $\begin{array}{c}\text { \% of } 2019 \text { net } \\
\text { assets }\end{array}$ & Net profit in 2019 & $\%$ of 2019 net profit \\
\hline Transfered out & $-55,770.89$ & $-1.46 \%$ & $-70,270.84$ & $-70.63 \%$ \\
\hline Tranfered in & $102,587.73$ & $2.68 \%$ & $17,538.44$ & $17.63 \%$ \\
\hline Net transfer (in - out) & $158,358.62$ & $4.14 \%$ & $87,809.28$ & $88.26 \%$ \\
\hline
\end{tabular}

\subsubsection{Gratuitous transfer of assets}

On November 2, the shares of Zhongyuan Bank were transferred to Henan Investment Group, and the shares of Longyu Coal Chemical and the other four companies were transferred to its controlling shareholder. (Table 10) On November 9, 2020, Yongmei's rating agency, China Chengxin International published an announcement. In which, CNXI said that according to the corresponding audit report of the corresponding assets, the net effect is that RMB 1,583,586,200 worth of assets were transferred into the company, which accounts for $4.14 \%$ of the net assets of Yongmei's 2019 consolidated statement. Besides, these assets have a net profit of RMB878,092,800 in 2019, which equals $88.26 \%$ of Yongmei's consolidated net profit in 2019. CNXI believes that transferred out assets were mainly related to the chemical business, with high financial leverage and substantial losses in recent years. The gratuitous transfer will improve the company's asset quality, profitability and capital structure.[28] However, the Zhongyuan Bank shares are high-quality assets with high liquidity, transferring out them weakened Yongmei's solvency.

In general, although Yongmei negotiated with the corresponding debtholders to reach an extension after the default occurred, and has already paid part of the funds, its suspicion of evading debts still cannot be completely got rid of.

\subsection{Early Risks Warning}

Based on the analysis of Yongmei's bond default, it is possible to summarize indicators that can be used to warn similar corporate bonds' default risks.

- The debt ratio of the company is significantly higher in peer ranking and there is obvious behaviour of borrowing new debts to repay the old

- The proportion of corporate current liabilities has increased significantly and the current ratio and quick ratios are much lower than the industry standards

- The related parties of the bond issuer account for too many funds, especially when the bond issuer is only the parent company and a small number of subsidiaries contribute most of the profits.

- The transfer of high-quality or highly liquid assets occurs when the company's cash flow is inefficient.

- In the short to medium term, companies are facing debt maturity that is relatively large relative to unrestricted available cash.

\section{CONSLUSION}

\subsection{Research Conclusions}

Through the analysis of the bond default events of Yongmei, from the consolidated and parent company financial statements, Yongmei has the problem of excessive debt levels, too many short-term debts, and 
borrowing new debts to repay the old. The most important problem is that related parties account for too many funds. Therefore, although the monetary funds in the consolidated financial statements are sufficient, the parent company as the main bond issuer still has far less cash available in contrast to the need for short-term debt repayment. More importantly, this default even broke the "guarantee faith" of state-owned enterprises. Hence, when purchasing and assessing the risks of credit bonds, more attention should be paid to the issuers' reliable solvency. Besides, the rating model of the rating agency has problems that the data used does not reflect the bond issuer's situation and the net profit is completely ignored in the rating model.

\subsection{Suggestions Related to Above Analyses}

What needs to be prevented is that some local stateowned enterprises overdraft their credit, to "transfuse blood" to their weakly qualified subsidiaries.

\subsection{Bond issuers}

Enterprises should establish internal risk control mechanisms for risk assessments. Before issuing bonds, evaluating the company's debt situation and the pressure of debt repayment in years as if the bond were issued. To avoid the future that the company borrows new debts and repaying the old, and it is difficult to return. During the event, the company should monitor funds usage to get timely feedback and stop the improper use of funds. This is to prevent misappropriation embezzlement of funds by subordinate departments. After the default event, the debt issuer should actively negotiate countermeasures with debtholders, including debts repayment extension and bankruptcy reorganization, so that the enterprise has the opportunity to survive and operate to better repay debts later, and minimize the losses of both enterprises and creditors.

\subsection{Regulators, supervisory institutions}

Following the requirements of "building a system and zero tolerance", it is important to improve the information disclosure system. In addition, regulators and supervisory institutions should strengthen rules on information disclosure, due diligence, and continuous supervision. Consolidate the responsibilities of related personals and institutions, increase civil compensation and criminal accountability. Such as impose certain restrictions on the market financing of enterprises that maliciously evaded debts and incorporate relevant information into the credit investigation system and National credit information sharing platform. These can significantly increase the cost of violations of laws and relevant regulations, maintain the fairness and order of the bond market and promote the stable, and orderly development of the market.

\subsection{Institutional investors}

When purchasing bonds, institutional investors must not blindly trust the state-owned enterprises and the ratings of rating agencies. Instead, they must independently analyse the default risk of bond issuers and check reasons and analysis of rating agencies to make investment decisions comprehensively.

\subsection{Capital market intermediaries}

For rating agencies, it is necessary to adjust their rating model to exclude or reduce the proportion of "State-own enterprises Faith" in the score. At the same time, it is necessary to use scoring parameters matching the bond issuers real solvency to strengthen the accuracy of the scoring model, and better reflect the default risk of the rating subjects. If the parent company is the subject of debt issuance and repayment, the index derived from the data in the parent company's statement should be added to the rating model and the proportion should not be too low. In addition, for companies that have obvious behaviours similar to borrowing new debts to repay the old, the bond rating reports should point out it with sufficient analysis and emphasis. Furthermore, rating agencies should consider replacing some of the EBIT or EBITDA in the indicators with net profit to reduce the company's use of some expenses that are excluded from the rating to upgrade its rating.

\section{REFERENCES}

[1] Bai, J. (2020). A study on the causes and economic consequences of bond default of Wintime Energy. East China Jiao Tong University, 13-15.

[2] Hao, C., \& Zhu, F. (2020). The Construction and Application of China's Bond Risk Assessment Model under the Background of Default Tide. Development Finance Research, 3.

[3] Shi, Y. (2011). The credit risk evaluation Method of loans of non-manufacturing listed companies based on the study of a combination of Credit Metrics model and scoring model. Hangzhou Dianzi University, 6-10.

[4] Altman, E., Haldeman, R., \& Narayanan, P. (1977). A new model to identify bankruptcy risk of corporations. Journal of Banking and Finance, 2954.

[5] Altman, E. I. (1968). Financial Ratios, Discriminant Analysis and the Prediction of Corporate Bankruptcy. The Journal of Finance, 589-609.

[6] Altman, E., Fargher, N., \& Kalotay, E. (2011). A Simple Empirical Model of Equity-Implied Probabilities of Default. Journal of Fixed Income, 71-85. 
[7] Zhang, 1., \& Zeng, W. (2004). An Empirical Study on Credit Rating of Listed Companies in China Based on Z Vlaue Model. Journal of Finance and Economics.

[8] KMV.KMV and Credit Metrics [J]. KMV Corporation, 1997(2):124

[9] Jiang, Z. (2020). Default Charactersitcis of Credti Bond in China - empirical analysis based on logit model. Zhe Jiang University.

[10] Duan, X. (2012). Comparative study of applicability between Z-score model and KMV model in China. Southwestern University of Finance and Economics.

[11] Yu, L., Wang, T., \& Shang, T. (2016). Research on Default Problems and Countermeasures Credit Debt Market in China. Sourcewest Finance.

[12] Zhao, 1. (2018). Research on the Default Risk of Corporate Bonds under the Deleveraging Policy. Friends of Accounting.

[13] Zhang, K., \& Zhang, Z. (2020). The risk of corporate bond default and its prevention - Taking Wintime Energy as an example. Accountant, 7-9.

[14] Zhang, H. (2018). Research on the Characteristics, Influence and Countermeasures of Credit Bond Market Risk in China. South China Finance, 57-66.

[15] Gao, L. (2017). Risks, Problems and Countermeasures in the Development of China's Corporate Bonds. South China Finance, 58-65.

[16] Zhang, j. (2017). Risk Prevention of Corporate Bond Default - Taking Shanghai Chaori Solar Energy Science \& Technology as an example. Finance \& Accounting, 14-16.

[17] Hou, Y. (2020). Analysis of the Current Situation and Countermeasures of my Corporate Bond Default Handling in China. Shangye jingji, 172-173.
[18] Liu, Z., \& Li, Y. (2016). The Characteristics, Risks and Countermeasures of Credit Default in China's Bond Market. New Finance, 49-53.

[19] Feng, g., \& Duan, B. (2017). The legal logic of disposal of defaulted bonds. Journal of Law Application, 70-77.

[20] Ruan, h. (2019). The Construction of Transaction Market of Default Credit Debts. Commercial Research, 136-143.

[21] High Yield Bond Research Group of Golden Credit Rating. (2020). New Securities Law helps the development of the high-yield bond market. Chinabond, 39-42.

[22] Lu, G. (2011). Legal Discussion on the Evasion of Debts by Enterprises and the Protection of Rights of the Bank Financial Creditor. Financial Regulations, 40-43.

[23] Jin, J. (2016). Forms, Current Problems and Countermeasures of Enterprise's Default Debt. Macroeconomy, 57-59.

[24] Chen, W. (2019). Preventing financial risks, resolving and combating malicious evasion of debt. Legality Vision, 152.

[25] China Chengxin International Credit Rating Co., Ltd. (2020, 11 09). Announcement of China Chengxin International on Concerning the Gratuitous Transfer of Assets of Yongcheng Coal and Electricity Group Co., Ltd. From https://pdf.dfcfw.com/pdf/H2_AN2020111014279 14518_1.pdf?1605000993000.pdf

[26] China Chengxin International Credit Rating Co., Ltd. (2020, 04 27). From Credit Rating Report: https://pdf.dfcfw.com/pdf/H2_AN2020042213783 87100_1.pdf 